Vol. 1 No. 2 September 2021, p-2797-5592 | e-2797-5606

\title{
PENINGKATAN KINERJA GURU DALAM PENGEMBANGAN EVALUASI HASIL BELAJAR MELALUI SUPERVISI AKADEMIK KEPALA SEKOLAH DI SD NEGERI 5 SIDOREJO TAHUN PELAJARAN 2019/2020
}

\author{
ENDANG SETYOWATI \\ SD Negeri 3 Karangharjo \\ Email : endangsetyowati00@admin.sd.belajar.id
}

\begin{abstract}
ABSTRAK
Kelayakan mengajar tidak cukup hanya diukur berdasarkan pendidikan formal, tetapi juga harus diukur berdasarkan bagimana kemampuan guru dalam mengajar dan penguasaan materi, memilih dan menggunakan metode, media, serta evaluasi pembelajaran. Kemampuan guru SD dalam menguasai bahan pelajaran pada umumnya sangat memprihatinkan. Dari sampel guru SD yang diminta menunjukkan kemampuan menguasai bahan pelajaran, $70 \%$ kurang menguasai bahan pelajaran dan $30 \%$ menguasai bahan pelajaran. Kondisi tersebut terjadi karena kurang optimalnya fungsi pengawasan kepala sekolah. Selama ini banyak pendapat bahwa profesionalisme guru di Indonesia relatif rendah atau kurang memadai. Hal itu terjadi antara lain karena kurangnya kepengawasan kepala sekolah. Tujuan PTS ini adalah untuk mengetahui sejauh mana pembinaan kepala sekolah melalui supervisi akademik untuk meningkatkan kinerja guru dalam pengembangan evaluasi hasil belajar. Hasil penelitian terbukti dapat meningkatkan kinerja guru dengan mencapai standar ideal. Keberhasilan pada siklus I sebesar $61,43 \%$ meningkat menjadi $67,14 \%$ pada siklus II dan menjadi $75 \%$ pada siklus III. Bahwa pembinaan melalui supervivi akademik kepala sekolah dapat meningkatkan kinerja guru dalam pengembangan evaluasi hasil belajar dengan ketuntasan mencaapai $100 \%$.
\end{abstract}

Kata kunci: kinerja guru, evaluasi hasil belajar, supervisi akademik

\section{PENDAHULUAN}

Kinerja adalah ungkapan kemajuan yang didasari oleh pengetahuan, sikap, keterampilan, dan motivasi dalam menghasilkan suatu pekerjaan (Fattah, 2006). Menurut Supardi (2011) kinerja guru akan menjadi lebih baik jika seorang guru memiliki empat hal sebagai berikut. Pertama, mempunyai komitmen pada siswa dan proses belajarnya. Kedua, menguasai secara mendalam bahan mata pelajaran yang akan diajarkan serta cara mengajarnya kepada siswa. Ketiga, bertanggung jawab memantau hasil belajar siswa melalui berbagai cara evaluasi. Keempat, guru berpikir sistematis tentang aapa yang dilakukannyaa dan belajar dari pengalamannya.

Kelayakan mengajar tidak cukup hanya diukur berdasarkan pendidikan formal tetapi juga harus diukur berdasarkan bagaimana kemampuan guru dalam mengajar dan sesi penguasaan materi, menguasai, memilih dan menggunakan metode, media serta evaluasi pembelajaran. Sehubungan dengan hal itu, Jiyono (1987) menyimpulkan bahwa kemampuan guru SD dalam menguasai bahan pelajaran pada umumnya sangat menghawatirkan karena dari sampel guru SD yang diminta menunjukkan kemampuan menguasai bahan pelajaran $70 \%$ yang kurang menguasai bahan pelajaran, sedangkan hanya 30\% yang menguasai bahan pelajaran. Kondisi seperti itu diperparah dengan kurang optimalnya fungsi kepengawasan Kepala Sekolah. Bila selama ini banyak pendapat menyatakan profesionalisme guru di Indonesia relatif rendah atau kurang memadai, hal itu merupakan akibat dari kurangnya kepengawasan kepala sekolah.

Arifin (2000) berpendapat bahwa guru profesional di Indonesia pasti memiliki syarat sebagai berikut: (1) Landasan keilmuan yang kuat sebagai perwujudan dari kalangan teknis dan keilmuan pada abad ke-21. (2) Penguasaan keterampilan profesional bersumber pada pengkajiandan praktik pendidikan, yaitu ilmu pendidikan sebagai ilmu praktis bukan hanya sekedar persepsi. Pendidikan adalah sistem yang berlangsung ditempat dan bersifat ilmiah.Pengkajian pendidikan mestiditujukan kepada praktek pendidikan bangsa Indonesia. (3) 
Pengembangan kompetensi profesional secara berkepanjangan. Profesi guru merupakan profesi yang terus meningkat antara LPTK dengan praktik pendidikan.

Dalam penelitian ini penulis mencoba untuk mengkaji dan menggali supervisi (Kepala Sekolah) yang berkaitan dengan kinerja guru, disebabkan oleh: (1). Adanya kecenderungan melemahnya kinerja guru di mana berdasarkan pengalaman penulis menjadi Kepala Sekolah yaitu terjadinya guru yang membolos mengajar, guru yang masuk ke kelas yang tidak tepat waktu, guru mengajar tidak mempunyai persiapan mengajar, guru tidak punya absensi siswa, (2) adanya pelaksanaan supervisi yang dilakukan oleh kepala sekolah belum dilaksanakan dengan sebaik-baiknya kepada guru. Beberapa rekan penulis yang sama-sama menjabat menjadi Kepala Sekolah mengaku kurang serius dalam melaksanakan fungsinya sebagai supervisor, (3) adanya penurunan kinerja guru merupakan salah satu penyebab menurunnya Nilai UASBN siswa. Oleh karena itu perlu diungkap tentang supervisi Kepala Sekolah terhadap peningkatan kinerja guru di SDN 5 Sidorejo

Hipotesis tindakan dalam penelitian ini sebagai berikut. 1) Kinerja guru dalam pengembangan evaluasi belajar dapat ditingkatkanmelalui supervise akademik di SD Negeri 5 Sidorejo, Kecamatan Pulokulon tahun pelajaran 2017/2018. 2) penerapan supervise akademik kepala sekolah sanat efektif untuk meningkatkan kinerja guru dalam pengembangaan evaluasi hasil belajar di SD Negeri 5 Sidorejo, Kecamatan Pulokulon tahun pelajaran 2017/2018.

Untuk mengatasi permasalahan tersebut, guru merancang skenario pembelajaran yang mampu menggiring siswa menjadi lebih aktif dan tertarik untuk mengikuti pembelajaran. Penggunaan Megaseri (media gambar seri) diharapkan dapat mengatasi permasalahan siswa dalam menyajikan atau menulis teks fabel. Bertolak dari hal-hal tersebut, dalam penelitian diangkat judul Penggunaan Megaseri untuk Meningkatan Keterampilan Menulis Teks Fabel pada Siswa Kelas SD Negeri 5 Sidorejo Semester Genap Tahun Pelajaran 2019/2020.

Tujuan penelitian ini adalah sebagai berikut. 1) Meningkatkan kinerja guru dalam pengembangan evaluasi hasil belajar melalui supervisi akaddemik di SD Negeri 5 Sidorejo, Kecamatan Pulokulon tahun pelajaran 2017/2018. 2) Meningkatkan efektivitas penerapan supervise akademik kepalaa sekolah dalam meningkatkan kinerja guru dalam pengembangan evaluasi hasil belajar di SD Negeri 5 Sideorejo, Kecamatan Pulokulon tahun pelajaran $2017 / 2018$.

\section{METODE PENELITIAN}

Penelitian ini menggunakan Penelitian Tindakan Sekolah (PTS), tujuan utama dari PTS adalah untuk memperbaiki/meningkatkan praktek pembelajaran secara berkesinambungan, sedangkan tujuan penyertaannya adalah menumbuhkan budaya meneliti di kalangan guru. Sesuai dengan jenis penelitian yang dipilih, yaitu penelitian tindakan, maka penelitian ini menggunakan model penelitian tindakan dari Kemmis dan Taggart, yaitu berbentuk spiral dari sklus yang satu ke siklus yang berikutnya. Setiap siklus meliputi planning (rencana), action (tindakan), observation (pengamatan), dan reflection (refleksi) (Arikunto, 2007). Langkah pada siklus berikutnya adalah perencanaan yang sudah direvisi, tindakan, pengamatan, dan refleksi. Subyek dalam penelitian ini adalah Guru SDN 5 Sidorejo Kecamatan Pulokulon Kabupaten Grobogan tahun pelajaran 2017/2018. Jenis penelitian ini adalah penelitian tindakan sekolah melalui penerapan supervisi akademis Kepala Sekolah.

\section{HASIL DAN PEMBAHASAN}

\section{Hasil}

Siklus I

Pengamatan (observasi) dilaksanakan bersamaan dengan pelaksanaan pembinaan di sekolah. Pada akhir proses pembinaan Kepala Sekolah diberi tes formatif I dengan tujuan untuk mengetahui tingkat keberhasilan Kepala Sekolah dalam meningkatkan kinerjanya sesuai dengan yang telah dilakukan. Adapun data hasil penelitian pada siklus I. adalah seperti pada tabel berikut : 
Tabel 1. Tabel Distribusi Nilai tes Pada Siklus I

\begin{tabular}{|c|l|c|c|c|}
\hline \multirow{2}{*}{ No } & \multicolumn{1}{|c|}{ Nama } & Skor & \multicolumn{2}{c|}{ Keterangan } \\
\cline { 4 - 5 } & & & Tuntas & $\begin{array}{c}\text { Tidak } \\
\text { Tuntas }\end{array}$ \\
\hline 1 & $\begin{array}{l}\text { Ismi Juli } \\
\text { Astanti,S.Pd.SD }\end{array}$ & 80 & $\sqrt{ }$ & \\
\hline 2 & Miftakul Ulum & 60 & & $\sqrt{ }$ \\
\hline 3 & Giyanto,S.Pd & 70 & $\sqrt{ }$ \\
\hline 4 & Ayu Candra Mustika & 60 & & $\sqrt{ }$ \\
\hline 5 & Umi Rustanti,S.Pd & 60 & & $\sqrt{ }$ \\
\hline 6 & Siti Arofah,S.Pd.I & 50 & & - \\
\hline 7 & Kusno & 50 & & - \\
\hline Jumlah Total & $\mathbf{4 3 0}$ & - & - \\
\hline \multicolumn{2}{|l|}{ Skor Maksimum Individu } & $\mathbf{1 0 0}$ & - & - \\
\hline
\end{tabular}

Keterangan :

Jumlah Guru yang tuntas

Jumlah Guru yang belum tuntas

Kelompok Guru
: 2 Orang

: 5 Orang

: belum tuntas.

Dari tabel di atas dapat dijelaskan bahwa dengan pembinaan yang dilakukan oleh Kepala Sekolah melalui supervisi akademis diperoleh nilai rata-rata peningkatan kinerja guru adalah $61,43 \%$ atau ada 2 orang guru dari 7 orang sudah tuntas. Hasil tersebut menunjukkan bahwa pada siklus pertama secara kelompok guru belum meningkat kinerjanya, karena yang memperoleh nilai $\geq 65$ hanya sebesar $28,57 \%$ lebih kecil dari persentase ketuntasan yang dikehendaki yaitu sebesar $85 \%$. Hal ini disebabkan karena guru di SDN 5 Sidorejo Kecamatan Pulokulon masih banyak yang belum memahami tentang supervisi akademis kepala sekolah tersebut.

\section{Siklus II}

Adapun proses pembinaan mengacu pada rencana pembinaan dengan memperhatikan revisi pada siklus I, sehingga kesalahan atau kekurangan pada siklus I tidak terulang lagi pada siklus II. Penelitian tindakan sekolah ini dilaksanakan sesuai dengan prosedur rencana pembinaan dan skenario pembinaan pada saat proses belajar mengajar berlangsung. Pada akhir proses pembinaan guru diberi tes formatif II dengan tujuan untuk mengetahui tingkat keberhasilan dalam meningkatkan kinerjanya. Instrumen yang digunakan adalah tes formatif II. Adapun data hasil penelitian pada siklus II adalah sebagai berikut :

Tabel 2. Tabel Distribusi Nilai tes Pada Siklus II

\begin{tabular}{|c|l|c|c|c|}
\hline \multirow{2}{*}{ No } & \multicolumn{1}{|c|}{ Nama } & Skor & \multicolumn{2}{c|}{ Keterangan } \\
\cline { 5 - 5 } & & & $\begin{array}{c}\text { Tuntas } \\
\text { Tuntas }\end{array}$ \\
\hline 1 & $\begin{array}{l}\text { Ismi Juli } \\
\text { Astanti,S.Pd.SD }\end{array}$ & 80 & $\sqrt{ }$ & \\
\hline 2 & Miftakul Ulum & 70 & $\sqrt{ }$ & \\
\hline 3 & Giyanto,S.Pd & 75 & $\sqrt{ }$ & \\
\hline 4 & Ayu Candra Mustika & 70 & $\sqrt{ }$ & \\
\hline 5 & Umi Rustanti,S.Pd & 60 & & $\sqrt{ }$ \\
\hline 6 & Siti Arofah,S.Pd.I & 60 & & $\sqrt{ }$ \\
\hline
\end{tabular}


Vol. 1 No. 2 September 2021, p-2797-5592 | e-2797-5606

\begin{tabular}{|c|c|c|c|}
\hline \multirow{2}{*}{\begin{tabular}{c|c}
7 & Kusno \\
Jumlah Total
\end{tabular}} & 55 & & $\sqrt{ }$ \\
\hline & 470 & - & - \\
\hline Skor Maksimum Individu & 100 & - & - \\
\hline $\begin{array}{l}\text { Skormaksimum } \\
\text { Kelompok ( Guru ) }\end{array}$ & 700 & - & - \\
\hline
\end{tabular}

Keterangan :

Jumlah Guru yang tuntas

: 4 Orang

Jumlah Guru yang belum tuntas

: 3 Orang

Kelompok Guru

: belum tuntas.

Dari tabel di atas diperoleh nilai rata-rata peningkatan guru sekolah adalah $68,93 \%$ dan peningkatan kinerja mencapai $67,14 \%$ atau ada 4 orang dari 7 orang guru yang sudah tuntas dalam meningkatkan kinerjanya. Hasil ini menunjukkan bahwa pada siklus II ini peningkatan guru telah mengalami peningkatan sedikit lebih baik dari siklus I. Adanya peningkatan kinerja guru ini karena setelah Kepala Sekolah telah menginformasikan bahwa setiap akhir pembinaan akan diadakan penilaian sehingga pada pertemuan berikutnya guru lebih termotivasi untuk meningkatkan kinerjanya. Selain itu guru juga sudah mulai mengerti apa yang dimaksudkan dan diinginkan oleh Kepala Sekolah dalam melakukan pembinaan supervisi akademis kepala sekolah.

\section{Siklus III}

Pengamatan (observasi) dilaksanakan bersamaan dengan pelaksanaan proses belajar mengajar berlangsung. Pada akhir proses pembinaan guru diberi tes formatif III dengan tujuan untuk mengetahui tingkat keberhasilan guru dalam meningkatkan kinerjanya yang telah dilakukan. Instrumen yang digunakan adalah tes formatif III. Adapun data hasil penelitian pada siklus III adalah sebagai berikut :

Tabel 3. Tabel Distribusi Nilai tes Pada Siklus III

\begin{tabular}{|c|l|c|c|c|}
\hline \multirow{2}{*}{ No } & \multicolumn{1}{|c|}{ Nama } & Skor & \multicolumn{2}{c|}{ Keterangan } \\
\cline { 4 - 5 } & & & $\begin{array}{c}\text { Tuntas } \\
\text { Tuntas }\end{array}$ \\
\hline 1 & $\begin{array}{l}\text { Ismi Juli } \\
\text { Astanti,S.Pd.SD }\end{array}$ & 85 & $\sqrt{ }$ & \\
\hline 2 & Miftakul Ulum & 75 & $\sqrt{ }$ & \\
\hline 3 & Giyanto,S.Pd & 80 & $\sqrt{ }$ & \\
\hline 4 & Ayu Candra Mustika & 75 & $\sqrt{ }$ & \\
\hline 5 & Umi Rustanti,S.Pd & 70 & $\sqrt{ }$ & \\
\hline 6 & Siti Arofah,S.Pd.I & 70 & $\sqrt{ }$ & \\
\hline 7 & Kusno & 70 & $\sqrt{ }$ & \\
\hline \multicolumn{2}{|l|}{ Jumlah Total } & $\mathbf{5 2 5}$ & - & - \\
\hline Skor Maksimum Individu & $\mathbf{1 0 0}$ & - & - \\
\hline \multicolumn{2}{l}{$\begin{array}{l}\text { Skor Maksimum } \\
\text { Kelompok ( Guru ) }\end{array}$} & $\mathbf{7 0 0}$ & - & - \\
\hline
\end{tabular}

Keterangan :

Jumlah Guru yang tuntas

Jumlah Guru yang belum tuntas

Kelompok Guru

$$
\begin{aligned}
& \text { : } 7 \text { Orang } \\
& : \text { - Orang } \\
& \text { : Sudah tuntas }
\end{aligned}
$$

Berdasarkan tabel di atas diperoleh nilai rata-rata tes formatif sebesar $75 \%$ dari 7 guru secara keseluruhan sudah mencapai ketuntasan dalam meningkatkan kinerjanya. Maka secara kelompok ketuntasan telah mencapai $100 \%$ (termasuk kategori tuntas). Hasil pada siklus III ini mengalami peningkatan lebih baik dari siklus II. Adanya peningkatan hasil pembinaan pada siklus III ini dipengaruhi oleh adanya peningkatan kemampuan Kepala Sekolah dalam 
Vol. 1 No. 2 September 2021, p-2797-5592 | e-2797-5606

menerapkan pembinaan melalui supervisi akademis sehingga guru menjadi lebih memahami tugasnya sehingga dapat meningkatkan kinerjanya. Di samping itu ketuntasan ini juga dipengaruhi oleh kerja sama dari guru dengan Kepala Sekolah dalam merencanakan program kerja sekolahnya masing masing.

\section{Analisis Hasil Kegiatan}

Setelah dilakukan tindakan pada siklus 1, siklus 2 dan siklus 3 menunjukkan hasil sebagai berikut :

Tabel 4. Analisis Hasil Tes Tentang Pembinaan Kepala Sekolah Terhadap Peningkat
Kinerja Guru Melalui Supervisi
\begin{tabular}{|c|l|c|c|c|}
\hline No & \multicolumn{1}{|c|}{ Nama } & $\begin{array}{c}\text { Skor } \\
\text { sebelum } \\
\text { Tindakan } \\
\text { Siklus 1 }\end{array}$ & $\begin{array}{c}\text { Skor setelah } \\
\text { Tindakan 1 } \\
\text { Siklus 2 }\end{array}$ & $\begin{array}{c}\text { Skor } \\
\text { setelah } \\
\text { Tindakan 2 } \\
\text { Siklus 3 }\end{array}$ \\
\hline 1 & $\begin{array}{l}\text { Ismi Juli } \\
\text { Astanti,S.Pd.SD }\end{array}$ & 80 & 80 & 85 \\
\hline 2 & Miftakul Ulum & 60 & 70 & 75 \\
\hline 3 & Giyanto,S.Pd & 70 & 75 & 80 \\
\hline 4 & Ayu Candra Mustika & 60 & 70 & 75 \\
\hline 5 & Umi Rustanti,S.Pd & 60 & 60 & 70 \\
\hline 6 & Siti Arofah,S.Pd.I & 50 & 60 & 70 \\
\hline 7 & Kusno & 50 & 55 & 70 \\
\hline & Jumlah Total & $\mathbf{4 3 0}$ & $\mathbf{4 7 0}$ & $\mathbf{5 2 5}$ \\
\hline Skor Maksimum Individu & $\mathbf{1 0 0}$ & $\mathbf{1 0 0}$ & $\mathbf{1 0 0}$ \\
\hline Skor Maksimum Kelas & $\mathbf{7 0 0}$ & $\mathbf{7 0 0}$ & $\mathbf{7 0 0}$ \\
\hline
\end{tabular}

\section{Analisis Data Deskriptif Kuantitatif}

1. Pencapaian Peningkatan Kinerja Guru sebelum diberi tindakan

$$
=\frac{430}{700} \times 100 \%=61,43 \%
$$

2. Pencapaian peningkatan kinerja kepala sekolah setelah diberi tindakan melalui supervisi akademis oleh Kepala Sekolah

$$
=\underline{4700} \times 100 \%=67,14 \%
$$

3. Pencapaian peningkatan kinerja guru setelah diberi tindakan melalui supervisi akademis oleh Kepala Sekolah

$$
=\underline{525} \times 100 \%=75 \%
$$

Dari hasil analisis tersebut dapat disimpulkan bahwa

1. Terjadi peningkatan kinerja setelah diberi pembinaan melalui kelompok supervisi akademis Kepala Sekolah yaitu peningkatan kinerja $61,43 \%$ menjadi $67,14 \%$ ada kenaikan sebesar $=5,71 \%$

2. Dari sebelum pembinaan (siklus 1) dan setelah pembinaan oleh Kepala Sekolah sampai dengan (siklus 3) 67,14\% menjadi 75\%, dan dari (siklus 2) ke (siklus 3) juga ada peningkatan sebanyak $75 \%-67,14 \%=7,86 \%$.

3. Rata - rata kinerja guru sebelum diberi pembinaan 28,57 naik menjadi $100 \%$.

4. Dari Pembinaan pada siklus 2 dan setelah pembinaan melalui supervisi akademis Kepala Sekolah ( siklus 3 ) 67,14\% menjadi $75 \%$ berarti ada peningkatan kinerja sebanyak $75 \%$ $67,14 \%=7,86 \%$.

\section{Refleksi dan Temuan}


Berdasarkan pelaksanaan pembinaan yang telah dilakukan Kepala Sekolah kepada kepala sekolah melalui supervisi akademis Kepala Sekolah maka hasil observasi nilai, dapat dikatakan sebagai berikut :

a. Pertemuan pertama kegiatan pembinaan belum berhasil karena dalam pembinaan Kepala Sekolah masih terlihat guru belum begitu antusias karena mereka masih menganggap pembinaan Kepala Sekolah tersebut merupakan tugas baru yang diembannya ;

b. Pembinaan yang dilakukan melalui melalui supervisi akademis Kepala Sekolah, dalam hal kinerja guru belum tampak, sehingga hasil yang dicapai tidak tuntas.

c. Mungkin karena proses pembinaan yang menggunakan pembinaan melalui supervisi akademi Kepala Sekolah yang baru mereka laksanakan sehingga guru merasa kaku dalam menerapkannya.

d. Akan tetapi setelah dijelaskan, mereka bisa mengerti dan buktinya pada pertemuan kedua dan ketiga proses pembinaan Kepala Sekolah berjalan baik, semua kepala sekolah aktif dan lebih-lebih setelah ada rubrik penilaian proses, semua kepala sekolah antusias untuk mengikutinya.

\section{Pembahasan}

\section{Ketuntasan Hasil Pembinaan Kinerja Guru}

Melalui hasil penelitian ini menunjukkan bahwa pembinaan melalui supervisi akademis Kepala Sekolah memiliki dampak positif dalam meningkatkan kinerja guru, hal ini dapat dilihat dari semakin mantapnya pemahaman guru terhadap pembinaan yang disampaikan Kepala Sekolah (Kinerja guru meningkat dari siklus I, II, dan III) yaitu masing-masing 61,43\% ; $67,14 \%$; 75\% Pada siklus III kinerja guru secara kelompok dikatakan tuntas.

2. Kemampuan Kepala Sekolah dalam meningkatkan kinerja guru

Berdasarkan analisis data, diperoleh aktivitas guru dalam meningkatkan kinerjanya dalam setiap siklus mengalami peningkatan. Hal ini berdampak positif terhadap kinerja guru yaitu dapat ditunjukkan dengan meningkatnya nilai rata-rata kepala sekolah pada setiap siklus yang terus mengalami peningkatan.

3. Aktivitas Kepala Sekolah dan guru dalam Pembinaan melalui Supervisi Akademis ;

Berdasarkan analisis data, diperoleh aktivitas Kepala Sekolah dan guru yang paling dominan dalam kegiatan supervisi akademis adalah bekerja dengan menggunakan alat/media, mendengarkan/memperhatikan penjelasan Kepala Sekolah, dan diskusi antar antar guru dan Kepala Sekolah. Jadi dapat dikatakan bahwa aktivitas guru dapat dikategorikan aktif.

Sedangkan untuk aktivitas Kepala Sekolah selama pembinaan telah melaksanakan langkah-langkah metode pembinaan melalui supervisi akademis dengan baik. Hal ini terlihat dari aktivitas guru yang muncul di antaranya aktivitas membuat dan merencanakan program sekolah,melaksanakan, memberi umpan balik/evaluasi/tanya jawab di mana prosentase untuk aktivitas di atas cukup besar. Berdasarkan hasil penelitian di atas, peningkatan kinerja guru melalui supervisi akademis Kepala Sekolah hasilnya sangat baik. Hal itu tampak pada pertemuan pertama dari 7 orang guru yang ada pada saat penelitian ini dilakukan nilai rata rata mencapai ; 61,43\% meningkat menjadi 67,14\% dan pada siklus 3 meningkat menjadi $75 \%$.

Dari analisis data di atas bahwa pembinaan kinerja Kepala Sekolah melalui supervisi akademis Kepala Sekolah efektif diterapkan dalam upaya meningkatkan kinerja guru, yang berarti proses pembinaan Kepala Sekolah lebih berhasil dan dapat meningkatkan kinerja guru khususnya di SDN 5 Sidorejo Kecamatan Pulokulon, oleh karena itu diharapkan kepada para Kepala Sekolah dapat melaksanakan pembinaan melalui supervisi akademis secara berkelanjutan. Berdasarkan hasil penelitian diatas, peningkatan kinerja guru dalam pengembangan evaluas hasil belajar melalui supervisi akademik kepala sekolah kearah perubahan yang diinginkan mencapai $85 \%$ ketercapaiannya, maka kinerja guru tersebut dikatakan efektif. 
Vol. 1 No. 2 September 2021, p-2797-5592 | e-2797-5606

\section{KESIMPULAN}

Berdasarkan analisis hasil penelitian dan diskusi dapat disimpulkan sebagai berikut :

Pembinaan Kepala Sekolah dalam upaya meningkatkan kinerja guru melalui supervisi akademis Kepala Sekolah menunjukan peningkatan pada tiap-tiap putaran (Siklus). Aktivitas dalam kegiatan pembinaan menunjukan bahwa seluruh guru dapat meningkatkan kinerjanya dengan baik dalam setiap aspek. Peningkatan kinerja guru oleh Kepala Sekolah melalui melalui supervisi akademis Kepala Sekolah ini menunjukan peningkatan pada tiap-tiap putarannya. Aktivitas kepala sekolah menunjukan bahwa kegiatan pembinaan melalui melalui supervisi akademis Kepala Sekolah bermanfaat dan dapat membantu guru untuk lebih mudah memahami konsep peran dan fungsi guru sehingga kinerja guru dapat meningkat.

\section{DAFTAR PUSTAKA}

Arifin, I. (2000). Profesionalisme Guru: Analisis Wacana Reformsi Pendidikan dam Era Globalisasi. Simposium Nasional Pendidikan di Universitas Muhammadiyah Malang, Arikunto, Suharsini. (2007). Penelitian Tindakan Kelas. Jakarta : PT.Bumi Aksara.

Atmodiwiro, Soebagio dan Soenarto Tatosiswanto. (1991). Kepemimpinan Kepala Sekolah. Semarang: Adhi Waskitho.

Jiyono. (1987). Cara Mengukur Mutu Pendidikan. Analisis Pendidikan. Jakarta : Rineka Cipta Nanang, Fattah. (2006). Landasan Manajemen Pendidikan. Bandung: Remaja Rosdakarya

Semiawan, Conny. (1985). Bagaimana Cara Membina Guru Secara Profesional. Jakarta: Journal Pendidikan.

Sergiovani, Cs. (1975). "Beyond Human Relations" Profesional Supervision for Profesional Teachers. Washington DC: Association for supervision and Curiculum Development. 1979. Supercision: Human Prepectives. New York: MeGraw-Hill Book Company.

Supardi. (2011). Penelitian Tindakan Kelas. Jakarta: PT Bumi Aksara.

Suyanto dan Djihad Hisya. (2000). Refleksi dan Reformasi Pendidikan Indoenesia Memasuki Millenium III. Yogyakarta : Adi Cita. 